\title{
Hybrid Learning Model in the Practic Subject
}

\author{
Yofita Sandra, Z. Mawardi Effendi, Atmazaki
}

\begin{abstract}
Hybrid learning model has been introduced in universities for a long time, but most of them take place to support instructional of theoretical learning. The application of hybrid learning models in practical subjects has never been exposed, especially for visual art education. This study was aimed to see how the development of a Quantum Working based Hybrid Learning Model (HQW) in the Graphic Arts Subject. Hybrid learning is intended to enrich the way of learning that so far has only focused on face-to-face activities.So by involving online learning, students can more freely search for varied and meaningful learning resources. When the references obtained have enriched their insights, it will be easy for students to express their ideas into two-dimensional or three-dimensional works of art.It is fully realized that there are limitations to the lecturers themselves, the completeness of campus facilities and infrastructure as well as the latest reference books.By combining face-to-face learning and online learning for the learning of art work practices, these weaknesses can be minimized.Students can make innovations from existing findings so that their work process becomes better, faster, and more efficient that we called Quantum Working.This research method is included in preliminary research $R \& D$ with the Borg and Gall model. The research data was obtained by distributing questionnaires to 114 students registered in the July-December 2019 semester and processed with a percentage formula, followed by interviews with lecturers who taught practicum subject.
\end{abstract}

Keywords: artwork practice, hybrid learning, quantum working.

\section{INTRODUCTION}

The implementation of learning by maximizing the potential of technology is not something new. This effort has long been applied in higher education. Through blended learning activities, learning that was originally only face-toface has shifted to online learning. However, there are still few findings that show that this learning is also applied in practical learning. There is a striking difference between practical and theoretical learning [1]. When ordinary theoretical learning is faced with optimizing cognitive and affective domains, practicum learning must optimize psychomotor abilities because it follows up on theoretical learning in the form of action. And the term practice does not always have to be in the laboratory, but can also take

Revised Manuscript Received on November 10, 2020.

* Correspondence Author

Yofita Sandra*, Department of Technology Instructional and Doctoral Program of Education Science, Universitas Negeri Padang, Padang, Indonesia, Email: yofita.sandra@fbs.unp.ac.id

Z. Mawardi Effendi, Departmentof Economic and Doctoral Program Education Science, Universitas Negeri Padang, Padang, Indonesia. Email: zmeffendi@fe.unp.ac.id.

Atmazaki, Department of Indonesian Language and Doctoral Program of Education Science, Universitas Negeri Padang, Padang, Indonesia, Email: atmazaki@fbs.unp.ac.id

(C) The Authors. Published by Blue Eyes Intelligence Engineering and Sciences Publication (BEIESP). This is an open access article under the CC BY-NC-ND license (http://creativecommons.org/licenses/by-nc-nd/4.0/) place outside the campus, for example: at home [2]. One way to develop practical courses that can also be done from home is by linking it with online learning. It would be very easy if online learning was an option for lecturers and students, but it would be different if it suddenly became a necessity. Usually, practical learning innovations apply a project-based learning model, and this is considered suitable for expressing students' beliefs in their abilities, solving problems, reflecting on, and evaluating themselves [3] Likewise, for research and implementation of art education development, the easiest way to apply is to create a concept map that combines verbal analysis and visual analysis to make it easier for art educators and prospective teachers to discuss art ideas in more depth even to practice in the field. Finding alternative materials to complete the assignment given by the lecturer is part of critical thinking [4].

Millar stated that the term practice refers to all learning activities that have important points to involve learners in observing, manipulating the objects, and material they are studying [2]. Meanwhile, the practice of making art supported by improvisation as the material for originality of work [5]. Fine art as a visual expression actually often appears in the form of cross-disciplines, cultures, and times, and combines new and traditional ways of creating as was done by Michael Beitz, who is a sculptor and works in painting, graphics, drawing [6]. In Indonesia, when fine arts including graphic arts were taught to students at the junior and senior high school levels, both were combined in the Field of Cultural Arts Studies. This can be done because they share many common aspects, principles, and processes [7]. As a practicum subject, the Graphic Arts Course is a branch of two-dimensional art whose beauty is enjoyed with the five senses of sight, namely the eyes. Graphic art is created through a printed medium called a cliché or matrix. The form of cliches can vary depending on the technique chosen. There are four techniques in printmaking; (1) relief print, (2) serigraphy, (3) intaglio print, and (4) planography. The relief print cliché is deliberately processed into the high and low parts and the high part is what produces the image, so it is called the high print. Meanwhile, serigraph cliches are processed into parts that are translucent or perforated. The translucent or perforated part produces the image, another name is filter printing. Meanwhile, the intaglio print cliché, deliberately processed by scratching, makes a difference between the high and low areas where the low part produces the image, known as deep printing. Finally, flat print when the cliché surface is flat or flat, only those who get the pigment either intentionally or not are the only ones that produce the image. This cliché allows a work of art to be multiplied to a maximum of 100 editions. Each edition is considered original because it represents the artist's innermost thoughts and feelings that are revealed to the public. If the printout of printmaking cannot be duplicated even through the printing process using clichés, then the identification of the work will be classified as a single print or monoprint.

Blue Eyes Intelligence Engineering \& Sciences Publication

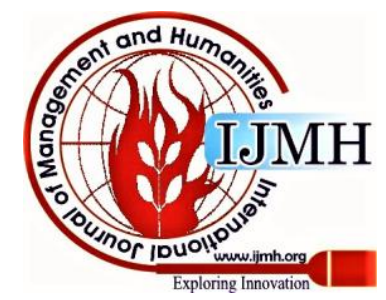


From work that was originally all manual, now it is starting to come into contact with digital technology [8]

There are many considerations to direct the implementation of graphic arts learning into online learning, especially hybrid learning. When learning that combines face-to-face learning systems and online learning refers to 10 subsystems as in open and distance learning, namely: (1) learning environment settings, (2) learning design, (3) student interaction with lecturers, and students with students, (4) places where practical activities take place, (5) implementation time, (6) adopted curriculum, (7) learning materials, (8) practice groups, (9) mastery of the required behavior or attitudes, and (10) learning support activities, the practice of creating graphic arts must also go through these 10 stages. Then to analyze each component and its role refers to (1) systems theory, (2) distance learning theory, (3) virtual learning groups, (4) learning design, (5) network flow measurement, (6) methods analysis of information feedback [9]. Clark [10] says: "By studying online, students can increase their learning initiatives. The task of the lecturer is to provide direct directions and guidance to find material on an ongoing basis"[10]. The direct direction is similar to face-to-face lectures where lecturers provide faceto-face directions, while guidance is to find new material or develop new material by researching certain theories, asking questions, discussions through online learning. The hybrid learning framework contains the following elements: (1) initiative, (2) interaction, (3) independence, (4) incentive, (5) improvement [10]. Combining practicum and online learning activities together is part of learning social constructionism [11]. This learning facilitates students to work and construct new knowledge by continuous interaction, sharing ideas, and working together in groups. Furthermore, the stimulus-response theory describe theory that can be applied in motor learning [12] Hybrid learning as part of online learning is not only blended learning but also mobile learning [13]. The hybrid learning model is realized as an application of sociocultural constructivism theory which departs from Piagetian-Based Constructivism thinking. Traditionally, the constructivism theory has focused on how a person constructs his or her own knowledge when dealing with certain knowledge content and actively processes interactions. This activity can take place individually or in groups. Constructivism based on Piaget's premise takes advantage of the process of assimilation, accommodation, and the process of balancing cognitive abilities when dealing with old and new knowledge that has generally been found during the cognitive development of children. When practicum courses are developed with a hybrid model of learning elements to become part of constructivist sociocultural activities, as proposed by Vigotsky, learning is more emphasized on the social and cultural environment, artifacts, tools, temporal elements, and the involvement of more skilled people. other for something more meaningful. The social environment determines the success of one's learning development [1416]. Maximum development of student abilities can be realized as formulated by Vygotsky in [17-19]. Foulger [20] says that the zone of proximal development (ZPD) is the main basis for the development of the real capability zone (zone of actual development-ZAP). By all means, the sense of art and the ability to create art can be taught through sustainable practice within the framework of modern society [20]. The requirements for learning graphic arts with a hybrid model are fulfilled if: (1) connected to the internet using an Android laptop or cellphone, (2) instructional process through video tutorials or documentary videos, (3) consulting assignments, discussions, and presentations using Moodle e-learning, and mobile app, and (4) implementation of evaluation using performance assessment rubrics and product assessment. Hybrid model learning in graphic arts practice courses is one of the best alternatives to face-to-face learning. Especially if the implementation of the learning is directed by students to be creative with tools or materials in the student environment. Utilization of the environment is part of Quantum Learning. Meanwhile, the role of lecturers to motivate students to work hard in all ways can be included in the learning section that applies Quantum teaching. When hybrid learning refers to practicum courses (by combining the two elements of Quantum Learning and Quantum Teaching) the learning is called Quantum Working (QW). The application of this model is in accordance with the demands of the times and art plays an important role in what forms of learning are developed by lecturers in teaching [21]. In fine arts learning, there have been notes on the implementation of learning to use a hybrid model as in the visual communication design course, while in the graphic arts course it has not [22]. Hybrid learning is also considered learning that combines traditional and digital learning messages, and is no longer just an option but has become a necessity [23]. The application of the hybrid model is rooted in the Social Development Theory (SDT) or Vigotsky's theory of social development to become the basis for learning constructivism [24]. At the same time, the application of this hybrid model becomes a multitasking pattern in adult learning [25]. The hybrid learning model is also part of digital literacy that prospective teachers must master. Digital literacy can be interpreted as the ability to access, manage, master, unify, communicate, evaluate, and produce information properly and accordingly using digital technology to work, get a decent job, and entrepreneurship [26]. In this case, digital literacy is also understood as proficiency in using computers, ICT, information, and media literacy. Art learning can also be carried out at home [27]. There has been researched in the field of art related to quantum learning by Clive which concluded that adequate initial knowledge is needed regarding the material being studied in the application of quantum learning, regardless of the field [28]. Lecturers must master across disciplines to teach successfully, and learning must contain material that contains technological elements or Pedagogical Content Knowledge [28]. Meanwhile, quantum working places more emphasis on how the tasks that are carried out can be done better, faster, and at a lower cost. The thought of working smart, fast, economical is considered part of entrepreneurial action and has become a trend in education today. In higher education, all courses have applied basic entrepreneurial development elements. And developing practicum learning with a quantum working-based hybrid model is also seen as in accordance with the trend of the application of ICT in learning. The following figure can explain how it works: (1) Road, sidewalk, irrigation and waterways technology, (2) simple tool to straighten eyebrows.

Blue Eyes Intelligence Engineering \& Sciences Publication

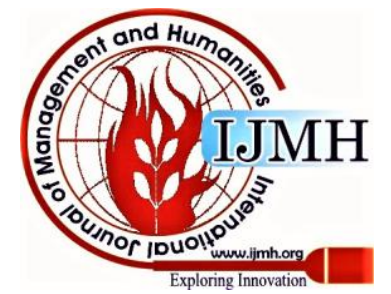




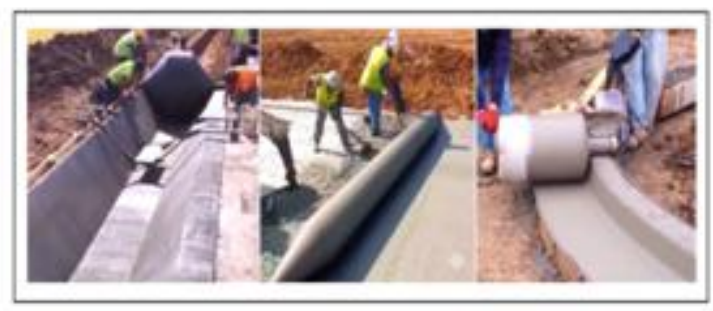

Figure 1. Road, sidewalk, irrigation and waterways technology [29]

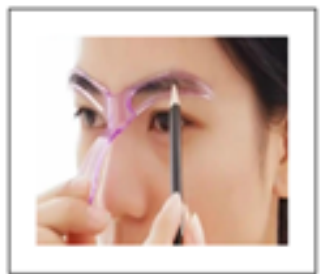

Figure 2. Simple tool to straighten eyebrows [30]

The name of the QW strategy can be attached to efforts to solve problems faced by students themselves. This is as reported by Anne and Emmanuel on the making of collaborative learning videos by students because of poor technical resources [31] In practice, these artists are at the same time as art workers whose daily work can be made of art while having fun with activities that are still relevant to art activities with many professions [32]. The application of the Quantum Working (HQW) Based Hybrid Model is based on Vigotsky's Social Development Theory, and Quantum Perspective Learning from Jansen, Perry \& Edward [33] The name Quantum Working is taken from the idea of Quantum Teaching and Quantum Learning, and many other types of Quantum learning, including The Quantum Mind [34]. HQW learning is certainly more dominated by psychomotor aspects. By including HQW elements in hybrid learning, the learning process and evaluation of learning outcomes also follow a hybrid model. One thing that is highly emphasized in quantum workingbased hybrid learning in this graphic arts course is the connection of lecturers and students in a network to be able to complete lecture assignments. In the end, lecturers indirectly evaluate student learning outcomes through an internet connection either in the form of photos or videos. The evaluated photo or video shows physical reactions and hand skills. The process that takes place can be started from a framework of access and motivation, then socialization that activities take place online, exchange information through social networks, construct new knowledge, and develop it [35]. As prospective art teacher students, each of them is faced with the challenge of being able to spread their knowledge and skills to middle and high school level students, including when art learning is only seen as an insertion because it is not a core subject in junior high and high school [36]. And this high school period is considered the most decisive to help and make it easier for students with visual-spatial intelligence to pursue the fields they master in college later. And even if students are from SMK, it is hoped that this intelligence will make it easier for them to join the business and industrial world smoothly. The art department as a factory for art teachers is expected to produce graduates with multidisciplinary and multitasking abilities.Comparing with art education in several countries, art education in Indonesia is among the least part of the number of hours of study, especially in junior and senior high school education because it is only served in the field of arts and cultural studies which average 2 lessons a week. Face-to-face learning hours have included education in music, dance, and drama. Even though this art education has a major effect on student learning success. Fine arts teachers have an important role in honing students' visual-spatial intelligence. For students, the more they see, the easier it is for them to analyze the information they receive. Because teachers who use fine arts learning tools when explaining learning are able to attract student attention and enthusiasm more than teachers who do not have visual learning tools. And actually, this visual art media also functions to link several disciplines as well as to become life skills [37]. It is no exaggeration to say that teaching fine arts is as important as teaching English, social sciences, general knowledge, and mathematics [38]. Several countries have made art education the main subject that must be taught to students and packaged in science, technology, engineering, arts, and mathematics (STEAM). Art education is integrated with other fields of study so it becomes a cross-disciplinary and multitasking subject [39]. Knowledge of fine arts will be very useful in the professional and business fields after students have invested their education. And this effort is included in the entrepreneurship movement. Unfortunately, although many lecturers realize that it is important and necessary to apply entrepreneurial principles, many do not apply them in the implementation of learning [40].

\section{METHODOLOGIES}

This research was conducted using the $R \& D$ procedure in the preliminary research phase of Borg and Gall. This model was chosen because it is considered suitable for finding solutions to problems faced in the field. This research was conducted in West Sumatra. The data taken in the research came from the Fine Arts Department, FBS UNP. The data analysis technique used is descriptive quantitative analysis technique. This quantitative descriptive technique is calculated according to the percentage of answers given by respondents based on the score:

$$
V=\frac{\mathrm{X}}{Y} \mathrm{x} 100 \%
$$

Note: $(\mathrm{V}=$ final result; $\mathrm{X}=$ score obtained, $\mathrm{Y}=$ maximum score)

Data collection techniques were collected by making observations, distributing questionnaires, and conducting interviews. During the observation, important data is recorded and the photo documentation is taken. Interviews are held outside of class hours with lecturers who are teaching the Graphic Arts subject to find out how to teach the lecturer, the tools used, and how to create a learning atmosphere that is conducive to the practice of artwork. Student analysis was carried out by distributing questionnaires to selected students as a sample to determine student characteristics. From the results of the interview, information was obtained regarding the problems faced by lecturers in implementing HQW learning. And from the evaluation of the learner's analysis the potential to be used as signs for developing the HQW learning model.

Published By:

Blue Eyes Intelligence Engineering \& Sciences Publication

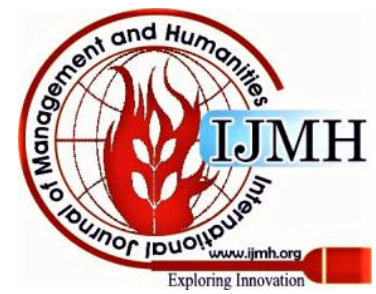




\section{Hybrid Learning Model in the Practic Subject}

\section{RESULT AND DISCUSSION}

\section{Curriculum and Learning Tools}

There are two courses listed as material that provides provisions for mastery of information technology. The subjects consist of Basic Statistics and Computer Applications and Fine Arts Learning Media. These two subjects, the course development scheme was not too intense with what is currently needed in learning fine arts. For example, for a basic statistics course, 1 credit of theory and 2 credits of practice is mentioned, totaling 3 credits. There is not much material closeness to the development of creating fine arts, although there is a significant contribution to students who take the thesis pathway with quantitative research. Furthermore, Computer Application and Fine Arts Learning Media courses, both have 1 theoretical credit and 2 practical credits, with a total of 3 credits. However, in the development of learning in this subject, the learning orientation focuses on processing visual forms only. For example, applying Corel Draw and Photoshop to create banner designs or logos. There has been no development that is oriented towards combining audiovisual and video sharing as is currently the trend for Vlog which is believed to be important for the development of graphic arts practice courses and other courses that require special time offcampus to complete lecture assignments that are practicum in nature.

\section{Facilities and Infrastructure}

There is no special place to clean the appliance after work. The side of the building is used to maximize cleaning work after practice. And there is no special room to exhibit the best work of students or the room to assess the final work of students apart from the Ibenzani Usman Gallery and the Adrin Kahar Gallery as an exhibition space as well as an examination room for painting and graphic final works.

\section{Learner Characteristics}

From the questionnaire distributed to 114 students midDecember 2019, with instruments that collect related information 1) student enthusiasm for learning; 2) work commitment/responsibility; 3) perceptions about the Constitutional Court. Practice; 4) ability to analyze problems (Inquiry); 5) readiness to learn; 6) basis for thinking / making decisions; 7) appreciation of fine arts; and 8) discovery. It is assumed that these eight items contribute to the learning outcomes of graphic arts based on findings that have been developed by previous researchers.

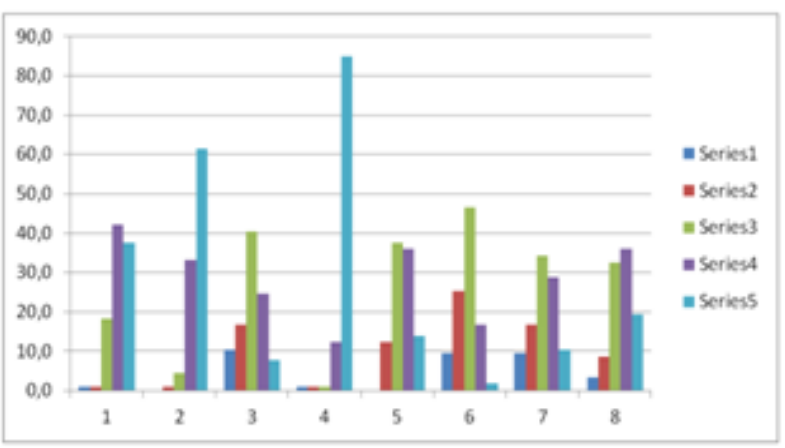

Figure 3. Students'readyness to hybrid learning

Series for students who responded: (1) negative-very bad,(2) negative-not good, (3) moderate-sufficient, (4) positivegood response, (5) positive-very good response.
These Indicators are used to capture information related to student characteristics of the importance of implementing a quantum working based hybrid learning model:

(1) student enthusiasm for learning, (2) work commitment/responsibility, (3) perceptions of practical subject, (4) ability to analyze problem-inquiry, (5) readiness to learn, (6) a basis for thinking/making decisions, (7) appreciation of fine arts, (8) discovery.

\section{Human resources}

From four lecturers who teach graphic arts courses, not even one lecturer has implemented a quantum workingbased hybrid learning model. Several lecturers have provided lecture materials that are uploaded on e-learning as well as forms of assignments. However, no one has yet created a means of communication for consulting tasks with a hybrid model, such as using social media and blogs or YouTube. And until now there has been no rubric for assessing the process of student work in the form of photos or videos that can be accessed by limited groups and/or the wider community for the purposes of process evaluation and product evaluation. Today, only Dr. Budiwirman, M.Pd, who makes reports on works and books on Google Play, but students cannot upload them freely (paid) - interview on December 20, 2019. Meanwhile, for the sake of learning the Hybrid model based on quantum working in the graphic arts practice course in the department in fine arts, it is planned that all learning resources can be accessed without having to pay. Furthermore, Mr Drs. Ariusmedi, M.Sn, and Mr Drs. Irwan, M.Sn (both of them) have never applied this hybrid learning model for graphic arts practice courses. While the author himself has tried to take advantage of existing facilities on social media features on adroit mobile phones such as WA and Facebook, but it is not structured and is not listed in the Semester Learning Plan, and the rubric is not systematic.

\section{Educational personnel services}

There are two education staffs in the Fine Arts Department, both of whom work in the department's office space side by side with the head and secretary of the department. From these two education staff, information has been collected regarding the application of online-based learning (online). Both reports that blended learning and hybrid learning have been implemented. However, no accurate data was obtained regarding physical evidence and the intended hybrid learning mechanism. There is no rubric and no RPS that includes learning hybrid models.

\section{Educational fees}

So far, the cost of implementing practicum learning has been handled by the department. With students paying UKT, almost $90 \%$ of the equipment and materials needed have been provided by the department. Only stationery and drawing tools are borne by students. Meanwhile, the materials and tools provided by the students were mainly related to the finishing process. Usually the tools and materials used are related to frames and glass to display works. It is recorded that the department's budget for student practicum per person per semester is IDR 900,000 (2018 majors accreditation form data) and this fee is considered large enough to complete all practicum assignments for one semester.

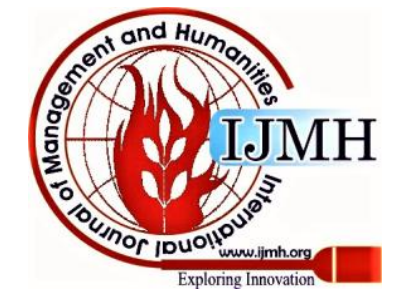




\section{CONCLUSION}

In this research, all indicators that are considered to be considered for the application of quantum working-based hybrid learning have been identified. This preliminary research has succeeded in uncovering the following findings: (1) the curriculum and learning tools have referred to efforts to achieve level 7 of the IQF but have not included quantum working-based hybrid model learning, (2) the facilities and infrastructure are complete, moreover, the campus has provided facilities for students so it will be easy to connect to the internet anytime anywhere with a wifi.id, (3) student characteristics detected from soft skills, enthusiasm for learning, commitment, perceptions of practical subjects, inquiry abilities, readiness to learn, foundations for scientific thinking and taking decisions, appreciation of work, abilities make discoveries that on average indicate a good level, meaning that they are ready to accept quantum working based hybrid model learning, (4) lecturers who teach art practice courses have not implemented online or network learning, (5) the involvement of educational staff means meaning in ensuring documenting all activities studying on campus. (6) the cost of education to carry out practical learning is large even though it has been subsidized by the campus, most of the materials that must be provided by students themselves here the role of quantum working will make it easier for students to find solutions to limited tools and materials to continue working with the material that is around. Based on these findings, it is considered important to follow up on these findings to the stage of needs analysis and initial product development related to the development of a quantum working-based hybrid model in the Graphic Arts Practical subject because it relates to efforts to create art education graduates who master digital skills in fine arts learning [41].

\section{ACKNOWLEDGMENT}

This prelimanary research was carried out due to the assistance of many parties, especially the head of the UNP Fine Arts Department, Drs. Mediagus, M.Pd, senior lecturer in the graphic arts subject Dr. Budiwirman, M.Pd and former dean of FBS Prof. Dr. M. Zaim, M.Hum.

\section{REFERENCES}

1. Zimmerman Nilson, M, "Practical and Theoretical Knowledge in Contrast: Teacher Educators' Discursive Positions," Australian Journal of Teacher Education, 42 (8), 2017, 28-42.

2. Said, Z. Developing a Framework for Effective Delivery of Practicals in Science Teaching in the State of Qatar. International Journal of Educational Science and Research (IJESR), Vol.6, Issue 2, 2016, 2534.

3. Tsai-Yun, M. Students' Evaluation of Their Experiences with ProjectBased Learning in a 3D Design Class. Asia-Pacific Education Researcher, v29 n2, 2020, 159-170.

4. Kristiyanto, W. G. The Effect of the Science Technolgy Society and the Quantum Teaching Models on Learning Outcomes of Students in the Natural Science Course in Relation With Their Critical Thinking Skills. International Online Journal of Education and Teaching (IOJET), 7(1), 2020, 177-191.

5. Pariser, D. Arts-based Research: Trojan Horses and Shibboleths. The Liabilities of a Hybrid Research Aproach. What Hath Eisher Wrought? Canadian Reviiew of Art Education (36), 2009, 1-18. tools and materials are needed, but there are tools or

6. Mary, H. Michael Beitz: Objects of Communication. Art Education, $v 67$ n3, 2014, 47-54.

7. Carpenter, T. E. Building Bridges with Bach: Syntegration of Music and Visual Art. General Music Today, v32 n3, 2019, 37-42.

8. Black, J. C. Promising Practices in Higher Education: Art Education and Human Rights using Information, Communication Technologies (ICT). Journal of Inquiry \& Action in Education, 6(1), 2014, 33-50

9. Le, J. The Strategy and Practice of Blended Learning in Open and Dstance Learning: Experiences frof GDRTVU. Hyrid Learning and Education, 2008, 294-302.

10. Wong, A. T. A Design Framework for Hybrid Learning. Hybrid Learning and Education, 2008, 324-333.

11. Parmaxi, A. Developing a framework for social technologies in learning via designn-based research. Educational Media International, 52(1), 2015, 33-46.

12. Umarisandi.

Gerak-Motorik.

2015. http://umarisandi.blogspot.com/2014/05/gerak-motorik.

13. Wang, M. Assesing the Effectiveness of Mobile Learning in Large Hybrid/Blended Classrooms. Hybrid Learning and Educaton, 2008, 304-312.

14. Schrader, D. Constructivism and Learning in the Age of Social Media: Changing Minds and Learningn Communities. New Directions for Teaching and Learning, 2015, 23-35.

15. Baviskar, N. Essential Criteria to Characterize Constructivist Teaching: Derived from a review of the literature and pplied to five constructivistteaching methods articles. . International Journal of Science Education, 2009, 541-550.

16. Tabassum, N. (2017, 04 17). Social Constructivism. Retrieved 029 , 2020, from Slideshare.net: https://www.slideshare.net/NoushiaNoushiaTabass/socialconstructivism-75101092

17. Churcher, K. E. Friending' Vygotsky: A Social Constructivist Pedagogy of Knowledge Building Through Classroom Social Media Use. . Journal If Effective Teaching, 14 (1), 2014, 33-50.

18. Siemens, G. Connectivism: A learning theory for the digital age. International Journal of Instructional Technology and Distance Learning, 2005, 3-10.

19. Foulger, T. S. Studenst's Role in Exposing Growing Pains: Using the "Dean's Concerns" to Refine Hyrid Instruction. . International Journal of Teaching and Learning in Higher Education , 2011, 150-165.

20. Miralay, F. \&. Aesthetic Perception of art Educators in Higher Education Level at Art Classes and Their Effect on Learners. Cypriot Journal of Educational Sciences, 14(2), 2019, 352-360.

21. Boothe, K. A. Enhancing Student Learning in the Online Instruction Environment Through the Use of Universal Design for Learning. Networks: An Online Journal for Teacher Research: Vol.22: Iss.1 https://doi.org/10.4148/2470-6353.1310, 2020, 1-24.

22. Sloan, K. A Work of Art, Mass College of Art and Design's new Partnership with the State. New England Journal of HIgher Education, 2009, 28-30.

23. Gerald P., M. \&. Student Preferences for a Hybrid Course. Journal of Education for Business, v92 n3, 2017, 105-113.

24. Edwards, M. P. Using the Artistic Pedagogical Technology of Photovoice to Promote Interaction in the Online Post-Secondary Classroom: The Students' Perspective. The Electronic Journal of eLearning Volume 10 issue 1, 2012, 32-43.

25. Karen, E. A. Patterns of Multitasking Behaviours of Adolescents in Digital Environtments. Education and Information Technologies, v25 $n 1,2020,623-645$.

26. Anisimova, E. S. Digital Literacy of Future Preschool Teachers. Journal of Social Studies Education Research, 11(1), 2020, 230-253.

27. Katie, B. The Challenges of Facilitating Arts Learning in Home Education. British Education Research Journal, v45 n5, 2019, 961-978.

28. Birgit, F. N.-B. (2020). Experienced Technology Teachers' Teaching Practices. International Journal of Technology and Design Educaton, v30 n1, 163-186.

29. Kacong, "Road, sidewalk, irrigation and waterways technology," (2019, April 28) Facebook. Available: https://www.facebook.com/781587481894458/videos/5501529654773 $\underline{03}$

30. Laris Total, "Simple tool to straighten eyebrows," https://laristotal.com

31. Anne, C. \&. Collaborative Amateur Production of Educational Videos, Which Are Viewed on Mobiles: Addressing Poor Technical Resources for Nigerian Creative Arts Academics. International Journal of Art \& Design Education, v38 n1, 2019, 110-124.

Blue Eyes Intelligence Engineering \& Sciences Publication

Journal Website: www.ijmh.org 


\section{Hybrid Learning Model in the Practic Subject}

32. Neal, A.-S. J. The Practice of an Artist Who Is Also an Arts Worker. Art Education, v67 n2, 2014, 43-52.

33. Edwards, M. P. Using the Artistic Pedagogical Technology of Photovoice to Promote Interaction in the Online Post-Secondary Classroom: The Students' Perspective. The Electronic Journal of eLearning Volume 10 issue 1, 2012, 32-43.

34. Elizabeth, O. S. Teachers' Assesment Experiences and Perceptions in the Practical Aesthetic Subjects. Scandinavian Journal of Educational Research, $v 60$ n 6, 2016, 649-662.

35. Huda, F.A. (2017, Maret 6). Penilaian psikomotorik. Retrieved from Fatkhat.web.id: http://Fatkhan.web.id/penilaian-psikomotor.

36. Elizabeth, O. S. (2016). Teachers' Assesment Experiences and Perceptions in the Practical Aesthetic Subjects. Scandinavian Journal of Educational Research, $v 60$ n 6, 649-662.

37. Nicola, G. The More We Look, The Deeper It Gets: Transforming the Curriculum through Art. 2018. New York: Rowman \& Littlefield Publishers, Inc.

38. Opoku-Asare, N. T.-M. Perceptions, Attitudes and Institutional Factors that Inflluence Academic Performance of Visual Arts Students in Ghana's Senior High School Core Curriculum Subjects. Journal of Education and Practice. ISSN 2222-1735 (Paper) ISSN 2222-288X (Online), 2015, 39-49.

39. Dell'Erba, M. Expanding Acess to High-Quality Arts Instruction. National Association of State Boards of Education, 2020, 10-12.

40. Marco, T. Arts Entrepreneurship Education in the UK and Germany: An Empiirical Survey among Lecturers in Fine Art. Education \& Training, v59 n4 , 2017, 406-426.

41. UNESCO-UIS. A Global Framework of Reference on Digital Literacy Skills for Indicator 4.4.2. 2018. Retrieved 3 7, 2020, from www.unesco.org: http://www.unesco.org/open-access/terms-useccbysa-en

\section{AUTHORS PROFILE}

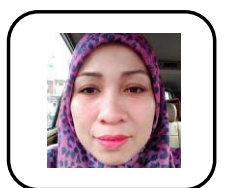

Yofita Sandra is a lecturer at the Department of Fine Arts Education, Faculty of Languages and Arts, Universitas Negeri Padang. Educational background's of author is a bachelor's degree in Fine Arts Education, and a Masters in Educational Technology. The main duty is to teach Printmaking, Metal Crafts and Art History Subject. Today is completing a doctoral program in the field of Education Science, concentration in Educational Technology. Since 2017 has concentrated on developing practical art learning that combines face-to-face systems with online learning. Apart from teaching, author also carry out research and community service through entrepreneurhship development in a team.

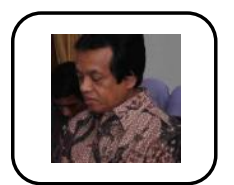

Z. Mawardi Effendi is a professor at the Faculty of Economics, Universitas Negeri Padang. Born on November 4, 1950 in Koto Panjang, Tanah Datar, West Sumatera, Indonesia. The professor in economics, who served as Chancellor of Universitas Negeri Padang for two periods from 2003 to 2007, was then re-elected from 2008 to 2012. Author also active in conducting research and collaborating with universities abroad, such as France, Australia and Malaysia. This collaboration has made UNP lecturers continue their studies abroad easier. Various articles have been published at the national and international levels discussing blended learning and the application of technology in learning, both theoretical and practical.

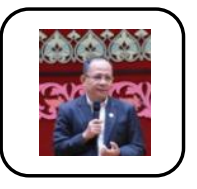

Atmazaki is a profesor at Indonesian Language Learning at Indonesian Language Education Program, Language and Art Faculty in Padang State University since 1994. Bachelor program of Indonesia Language Educational in IKIP Padang at 1983. Magister Program of Indonesian Language Program in IKP Bandung at 1992. At 2004 has graduated Language Eduacational Doctoral Program in Jakarta State University. Specifick research in assesment, material, methodology in Indonesian Language Learning. He has be presenter in some title such as DevelopingContext- BasedReadingMaterial, Authentic Assessment inLanguageTeaching, TheUseofAuthentic TeachingMaterials BasedonLocal, TeachingIndonesian Language forForeigner:The Infulence of CultureandLocal Languages, TheImplementationof K-13inIndonesian languageSubjek: Mindset, Scientific Approach,Genre, dan Assessment.

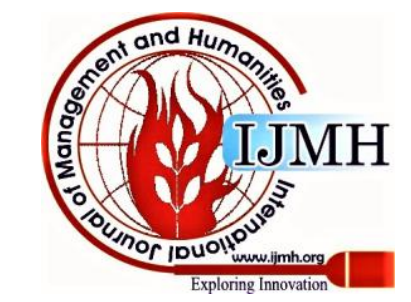

